\title{
EFFECTS OF CAPTAN ON THE GERMINATION OF WHITE SPRUCE, JACK AND RED PINE SEED
}

\author{
By J. H. CAYFORD ${ }^{1}$ and R. M. WALDRON ${ }^{2}$
}

Oxf. 443.2:232.318:174.7

\begin{abstract}
Several greenhouse experiments were carried out to study the effects of Captan-50W on the germination of white spruce, jack and red pine seed. Results indicated that Captan-50W was phytotoxic to seeds of these species but its effect on germination varied depending upon sowing method. It significantly increased total germination of surface-sown seed and decreased germination of depth-sown seed; for both sowing methods it increased the proportion of abnormal germinants. The net effect was to decrease the number of normal germinants both for depth and surface sowing; the decrease was much greater with surface sowing.
\end{abstract}

\section{EXTRAIT}

Résultats de plusieurs expériences en serre sur l'effet du Captan-50W sur le taux de germination des graines d'Epinette blanche (PICEA GLAUCA (Moench) Voss), de Pin gris (Pinus banksiana Lamb.) et de Pin rouge (PinUs Resinosa Ait.). Ce produit chimique s'avère toxique pour les graines mais ses effets sur la germination varient selon la méthode d'ensemencement: les graines semées en surface ont germé en plus grand nombre mais le contraire arriva pour les graines semées profondément dans le sol. Dans les deux cas, la proportion de jeunes plantes aberrantes a augmenté: de par ce fait, le nombre global des jeunes plantes saines produites a nettement diminué. La diminution a été plus forte dans le cas des ensemencements de surface.

\section{INTRODUCTION}

Treatment of tree seed with fungicides is an accepted technique in nursery practice to control losses due to damping-off; in field sowing, seeds are generally treated with bird and rodent repellents. However, in the province of Manitoba, Captan-50W ${ }^{3}$ a fungicide with certain rodent repellent qualities, ${ }^{4}$ has been applied to coniferous seed sown both in the field and in the nursery. Excellent germination has normally occurred in the nursery. However, results from field sowing have been variable and even in very favourable years germination failures have occurred.

\footnotetext{
${ }^{1}$ Assistant Program Coordinator, Silviculture, Department of Forestry and Rural Development, Ottawa, Ontario.

- Forestry Officer, Department of Forestry and Rural Development, Manitoba-Saskatchewan Region, Winnipeg, Manitoba.

${ }^{8}$ Captan - 50\%. Manufactured by Wilson Laboratories Ltd. Chemical name N-trichloromethylthiotetrahydrophthalimide.

- BUCKNER, C. H. 1963. The role of small mammals in the destruction of tree seeds. Dept. of Forestry, Forest Entomology Laboratory, Winnipeg, Manitoba. Unpubl. MS. 4 pp.
} 
Many chemicals are either phytoxic to tree seed or fail to give satisfactory control of damping-off. Results of a study of 109 chemicals by Vaartaja (1956) indicated that captan was one of only three tested at a wide range of concentrations that controlled the disease without marked phytotoxicity.

Effects of captan on the germination of tree seed have been reported by several investigators and it is evident that it is phytotoxic, at least to some extent. However, under conditions of severe damping-off the phytotoxicity of the chemical may be concealed by the beneficial effects of reducing damping-off losses (Cram and Vaartaja 1955, 1957, Labonte 1959, Vaartaja 1964, Vaartaja and Wilner 1956, Vaartaja et al. 1964, Weihing et al. 1961). As the direct phytotoxic effects of captan have been given only limited attention we undertook to determine its effects on germination of white spruce (Picea glauca (Moench) Voss), jack pine (Pinus banksiana Lamb.) and red pine (Pinus resinosa Ait.).

\section{METHODS}

Experiments were carried out in a greenhouse at Winnipeg, Manitoba. Environmental conditions were maintained as follows to provide for maximum germination: photoperiods averaged 15 hours of normal daylight supplemented by $480 \mathrm{ft}-\mathrm{c}$ from 14 fluorescent lamps. Maximum and minimum air temperatures averaged 78 and $69 \mathrm{~F}$ respectively; soil temperature at a depth of $1 / 2$ inch to 1 inch averaged $75 \mathrm{~F}$. Relative humidity was maintained at about 30 per cent. The germinating surface was kept moist by periodic watering.

Fifty or one hundred dewinged seeds were sown in waxed paper cups, $4 \frac{1 / 2}{2}$ inches in diameter and 3 inches in depth, filled with $400 \mathrm{~g}$ of mediumtextured sand. Seeds were sown either on the surface or at depths of $1 / 8$ to $1 / 2$ inch. A thin layer of vermiculite was placed in the bottom of the cups to permit rapid drainage of excess water through prepared holes.

White spruce seed collected in western Manitoba had a viability of 60 per cent; a small amount of this seed was cold-soaked for 25 days. Jack pine seed collected in southeastern Manitoba had a viability of 97 per cent and red pine seed collected in Minnesota a viability of 88 per cent. All seed was stored, untreated, in glass containers in a cold room at $35 \mathrm{~F}$.

In treating seed, methyl cellulose was used as the sticker and it was added until all seeds were coated. Dry captan powder was then applied, while sticker was still wet, at a rate of 12 per cent (active ingredient) by seed weight. Seed was sown the same day as treated according to statistical designs.

Observations were made at weekly intervals for 5 or 6 weeks after sowing. All germinants were classified as normal or abnormal; the latter had abnormal radicle development, did not attain an upright position, and often had little top development (Figure 1, p. 375).

Data from each experiment were subjected to analyses of variance after transforming germination percentages to angles by the arcsin transformation. Whenever 0 or 100 per cent occurred, a correction was made in which 0.25 was substituted for 0 , or $\mathrm{n}-0.25$ for $\mathrm{n}$, and the per cent recalculated (Bartlett 1945). Treatment means were compared by " $\mathrm{t}$ " tests; standard 
errors were calculated according to formulae presented by Cochran and $\operatorname{Cox}(1950)$.

\section{RESUlts AND Discussion}

The effects of captan varied depending upon whether seed was surfaceor depth-sown (Table 1). For surface-sown seed, captan increased total germination, except for jack pine, but also increased the percentage of abnormal germinants for all species. The net effect was to reduce the number of normal germinants per 100 jack pine, red pine, and cold-soaked white spruce seeds. For seed sown at a depth of $1 / 8$ inch, captan reduced total germination and increased the percentage of abnormality in those germinating, thereby decreasing the number of normal germinants. Considering only treated seed, depth sowing decreased the percentage of abnormal germinants and increased the number of normal germinants as compared with surface sowing.

Sticker (methyl cellulose) by itself affected neither total germination nor the percentage of abnormal germinants in surface-sown seed; phytotoxic effects therefore were due to captan. Percentage of abnormal germinants was 23 for untreated seed, 26 for seed treated with sticker, and 68 for seed treated with sticker and captan.

Variation in sowing density, from 1 to 64 treated jack pine seeds per $41 / 2$ inch diameter cup, had no significant effect on germination or on germinant development.

Results from sowing treated jack pine at a range of depths from $1 / 8$ to $1 / 2$ inch indicated no significant differences in germination for any of the depthsowing treatments. Also no differences resulted when treated seed was sown in an upright position with the hypocotyl end inserted into the soil and when it was depth-sown.

The phytotoxic effects appear to have resulted from injury to the root tips following germination. Injury to root tips of coniferous seedlings following contact with fungicides has been observed by Labonte (1959) and Jones (1963), while Voigt (1953) reported that various chemicals may inhibit the metabolism of roots of pine seedlings which would cause a decline in seedling development. Apparently root tip injury can result from contact with chemicals applied to the same seed, as sowing density was not a factor in phytotoxicity, at least in the case of surface-sown jack pine. The phytotoxic effects of captan were considerably reduced by sowing seed beneath a thin layer of soil.

These studies have shown that satisfactory germination can be obtained from captan-treated white spruce, jack pine, and red pine seeds sown beneath a thin soil covering. However, when pelleted seeds were surface-sown, germinants were largely abnormal. This may explain the conflicting results of successful nursery sowing and unsuccessful field sowing in Manitoba. 
TABLE 1

EFFect of Captan on Germination of SuRfaCe- AND Depth-SOWN White SPRUCE JACK AND RED PINE SEED

\begin{tabular}{|c|c|c|c|c|c|c|c|}
\hline \multirow[t]{2}{*}{ Species } & \multicolumn{2}{|c|}{$\begin{array}{l}\text { Total germination } \\
\text { (\% of seed sown) }\end{array}$} & \multicolumn{2}{|c|}{$\begin{array}{l}\text { Abnormal germinants } \\
\text { (\% of geed germinated) }\end{array}$} & \multicolumn{2}{|c|}{$\begin{array}{l}\text { Normal germinants } \\
\text { (\% of beed sown) }\end{array}$} & \multirow[t]{2}{*}{$\begin{array}{c}\text { Number of } \\
\text { seeds per } \\
\text { treatment }\end{array}$} \\
\hline & Treated & Untreated & Treated & Untreated & Treated & Untreated & \\
\hline \multicolumn{8}{|c|}{ Sarface-so wn } \\
\hline $\begin{array}{l}\text { White } \\
\text { spruce } \\
\text { White } \\
\text { spruce }\end{array}$ & $49 b^{1}$ & $28 a$ & $71 \mathrm{~b}$ & $21 a$ & $14 a$ & $22 a$ & 1,100 \\
\hline $\begin{array}{l}\quad C S^{2} \\
\text { Jack pine } \\
\text { Red pine }\end{array}$ & $\begin{array}{l}64 \mathrm{f} \\
92 \mathrm{j} \\
82 \mathrm{x}\end{array}$ & $\begin{array}{l}46 \mathrm{e} \\
85 \mathrm{j} \\
68 \mathrm{w}\end{array}$ & $\begin{array}{l}67 \mathrm{f} \\
76 \mathrm{k} \\
61 \mathrm{x}\end{array}$ & $\begin{array}{l}20 \mathrm{e} \\
14 \mathrm{j} \\
9 \mathrm{w}\end{array}$ & $\begin{array}{l}21 \mathrm{e} \\
22 \mathrm{j} \\
32 \mathrm{w}\end{array}$ & $\begin{array}{l}37 f \\
73 k \\
62 x\end{array}$ & $\begin{array}{r}400 \\
1,100 \\
1,100\end{array}$ \\
\hline \multicolumn{8}{|c|}{ Depth-sown } \\
\hline $\begin{array}{l}\text { White } \\
\text { spruce } \\
\text { Jack pine } \\
\text { Red pine }\end{array}$ & $\begin{array}{l}59 a \\
59 j \\
74 w\end{array}$ & $\begin{array}{l}70 \mathrm{~b} \\
88 \mathrm{k} \\
89 \mathrm{x}\end{array}$ & $\begin{array}{r}8 \mathrm{~b} \\
8 \mathrm{k} \\
22 \mathrm{x}\end{array}$ & $\begin{array}{l}1 \mathrm{a} \\
2 \mathrm{j} \\
2 \mathrm{w}\end{array}$ & $\begin{array}{l}54 \mathrm{a} \\
54 \mathrm{j} \\
58 \mathrm{w}\end{array}$ & $\begin{array}{l}69 b \\
86 k \\
87 x\end{array}$ & $\begin{array}{l}200 \\
200 \\
200\end{array}$ \\
\hline
\end{tabular}

1 For each species and method of sowing any two results not followed by the same letter differ significantly at the 5 per cent level.

Cold-soaked for 25 days.

\section{LiTERATURE CITED}

BARTLETT, M. S. 1945. The use of transformations. Biometrics $1: 39-52$.

COCHRAN, William G. and Gertrude M. COX. 1950. Experimental designs. John Wiley and Sons, Inc., New York. 454 pp.

CRAM, W. H. and O. VAARTAJA. 1955. Toxicity of eight pesticides to spruce and Caragana seed. For. Chron. 31:247-249.

CRAM, W. H. and O. VAARTAJA. 1957. Rate and timing of fungicidal soil treatments. Phytopath. 47:169-173.

JONES, Leroy. 1963. Germination of repellent-treated southern pine seed before and after storage. United States Dept. Agriculture, For. Serv., Southeast. For. Expt. Sta., Res. Note $\mathrm{SE}-15.4$ pp.

LABONTE, George A. 1959. Damping-off studies in coniferous seedlings. Maine For. Serv., Bull. 18, 14 PP.

VAARTAJA, O. 1956. Screening fungicides for controlling damping-off of tree seedlings. Phytopath. 46:387-390.

VAARTAJA, O. 1964. Chemical treatment of seedbeds to control nursery diseases. Bot. Rev. 30:1-91.

VAARTAJA, O. and J. WILNER, 1956. Field tests with fungicides to control damping-off of Scots pine. Can. J. Agric. Sci. 36:14-18.

VAARTAJA, O., J. WILNER, W. H. CRAM, P. J. SALISBURY, A. W. CROOKSHANKS and G. A. MORGAN.. 1964. Fungicide trials to control damping-off of conifers. Plant Disease Reptr. 48:12-15.

VOIGT, G. K. 1963. The effects of fungicides, insecticides, herbicides, and fertilizer salts on the respiration of root tips of tree seedlings. Soil Sci. Soc. Amer. Proc. 17:150-152.

WEIHING, John L., Robert INMAN and Glenn W. PETERSON. 1961. Response of ponderosa and Austrian pine to soil fumigants and seed treatments. Plant Disease Reptr. 45:799-802. 